\title{
Review of the status and conservation of tenrecs (Mammalia: Afrotheria: Tenrecidae)
}

\author{
P. J. Stephenson, Voahangy Soarimalala, Steven M. Goodman \\ Martin E. Nicoll, Vonjy Andrianjakarivelo, Kathryn M. Everson \\ Michael Hoffmann, Paulina D. Jenkins, Link E. Olson \\ Martin Raheriarisena, Felix RakotondRaparany \\ Daniel RakotondRavony, Vololomboahangy RandRianjafy \\ NANiE RATSifandRiHamanana and ANDREW TAYlor
}

\begin{abstract}
The mammal family Tenrecidae (Afrotheria: Afrosoricida) is endemic to Madagascar. Here we present the conservation priorities for the 31 species of tenrec that were assessed or reassessed in 2015-2016 for the IUCN Red List of Threatened Species. Six species (19.4\%) were found to be threatened (4 Vulnerable, 2 Endangered) and one species was categorized as Data Deficient. The primary threat to tenrecs is habitat loss, mostly as a result of slash-
\end{abstract}

P. J. STEPHENSON ${ }^{*}$ (Corresponding author, (1) orcid.org/0000-0002-0087-466X) IUCN SSC Species Monitoring Specialist Group, c/o Ecosystem Management Group, Department of Environmental Systems Science, ETH Zürich, Zürich, Switzerland. E-mail stephensonpj@gmail.com

Voahangy Soarimalala $\dagger$ (ㄷ) orcid.org/0000-0002-2455-2956) and Steven M. Goodman $\ddagger$ (ㅇ) orcid.org/0000-0001-9318-0570) Association Vahatra, Antananarivo, Madagascar

MARTiN E. Nicoll (@) orcid.org/0000-0003-2647-5808) Conservation Programme, WWF-Madagascar, Antananarivo, Madagascar

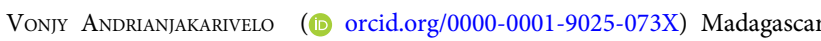
Program, Wildlife Conservation Society, Maroantsetra, Madagascar

Kathryn M. Everson (10 orcid.org/0000-0003-1495-7076) and Link E. Olson (1D) orcid.org/0000-0002-2481-5701) Department of Biology and Wildlife, University of Alaska Museum, Fairbanks, Alaska, USA

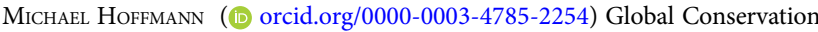
Programmes, Zoological Society of London, London, UK

Paulina D. Jenkins (10 orcid.org/0000-0002-8250-0601) Life Sciences Department, The Natural History Museum, London, UK

Martin Raheriarisena, Felix Rakotondraparany and Daniel Rakotondravony Mention Zoologie et Biodiversité Animale, Université d'Antananarivo, Antananarivo, Madagascar

Vololomboahangy Randrianjafy Faculté des Sciences, de Technologie et de l'Environnement, Université de Mahajanga, Mahajanga, Madagascar

Nanie RatSIFANDRIHAMANana WWF-Madagascar, Antananarivo, Madagascar

AndReW TAYlor (®) orcid.org/0000-0002-2896-5168) Wildlife in Trade Programme, The Endangered Wildlife Trust, Johannesburg, South Africa

${ }^{*}$ Also at: Science \& Knowledge Unit, IUCN, Gland, Switzerland

$\dagger$ Also at: Institut des Sciences et Techniques de l'Environnement, Université de Fianarantsoa, Fianarantsoa, Madagascar

¥Also at: Integrative Research Center, Field Museum of Natural History, Chicago, Illinois, USA

Received 10 May 2018. Revision requested 26 July 2018

Accepted 12 September 2018. First published online 30 April 2019. and-burn agriculture, but some species are also threatened by hunting and incidental capture in fishing traps. In the longer term, climate change is expected to alter tenrec habitats and ranges. However, the lack of data for most tenrecs on population size, ecology and distribution, together with frequent changes in taxonomy (with many cryptic species being discovered based on genetic analyses) and the poorly understood impact of bushmeat hunting on spiny species (Tenrecinae), hinders conservation planning. Priority conservation actions are presented for Madagascar's tenrecs for the first time since 1990 and focus on conserving forest habitat (especially through improved management of protected areas) and filling essential knowledge gaps. Tenrec research, monitoring and conservation should be integrated into broader sustainable development objectives and programmes targeting higher profile species, such as lemurs, if we are to see an improvement in the conservation status of tenrecs in the near future.

Keywords Afrotheria, conservation, IUCN Red List of Threatened Species, Madagascar, Microgale, Oryzorictes, Tenrecidae, threats

\section{Introduction}

The mammal family Tenrecidae (Supercohort Afrotheria: - Order Afrosoricida), endemic to the Indian Ocean island of Madagascar, contains 31 currently recognized extant species in three subfamilies: the Geogalinae (1 species), Oryzorictinae (25) and Tenrecinae (5). The tailless tenrec Tenrec ecaudatus has been introduced by humans to neighbouring archipelagos. Tenrecs exhibit a diverse array of body sizes and morphological, behavioural, physiological and ecological specializations, representing an adaptive radiation that is a model for evolutionary research (e.g. Eisenberg \& Gould, 1970; Stephenson \& Racey, 1995; Olson \& Goodman, 2003; Everson et al., 2016). 
Most tenrecs are dependent on forest habitats, and, with Madagascar having lost c. $40 \%$ of its forests in the last 50 years (Harper et al., 2007), the conservation status of many species is of concern. If the biodiversity of the country is to be conserved, its fauna and flora need to be assessed regularly and relevant conservation strategies must be developed.

The IUCN Red List of Threatened Species (IUCN, 2018; hereafter the IUCN Red List) is the most widely used tool for assessing the conservation status of species. Any new data for the IUCN Red List not only advances the knowledge needed to define conservation action but also provides countries with data against which to report on their environmental goals, such as those defined in the Aichi Targets and Sustainable Development Goals (Brooks et al., 2015).

Here we review the current conservation status of the Tenrecidae, as defined in the last species assessments conducted for the IUCN Red List in 2015-2016, with the aim of identifying trends in extinction risk, habitat needs and threats. We also identify conservation priorities to ensure a future for these poorly known small mammals. This is the first time the conservation needs of tenrecs have been compiled for almost 3 decades (Nicoll \& Rathbun, 1990).

\section{Methods}

We conducted this review in three stages. Firstly, during 2015-2016, we reassessed the status of all species in the Tenrecidae for the IUCN Red List (IUCN, 2018). Grandidier's shrew tenrec Microgale grandidieri had not been assessed before as it was described only in 2009 (Olson et al., 2009), subsequent to the last comprehensive assessment of all mammals (Schipper et al., 2008). Using information available for each species from the literature, such as the latest georeferenced distribution data collated by Goodman et al. (2013) and past and recent assessments of threats to and conservation priorities for tenrecs (e.g. Nicoll \& Rathbun, 1990; Stephenson, 1993a,b, 1994, 1995a; Stephenson et al., 1994; Jenkins et al., 2011; Nicoll \& Ratsifandrihamanana, 2014), and based on the assessors' knowledge, we collated data on geographical range (including area of occupancy or extent of occurrence), estimated population trends (or relative abundance), habitat use, life history traits, use and trade, threats, conservation actions currently in place and conservation actions needed. We then used this information to assess the risk of extinction for each species by applying the IUCN Red List categories and criteria (IUCN, 2012) which allowed us to assign each species to a category of threat ranging through Extinct, Extinct in the Wild, Critically Endangered, Endangered, Vulnerable, Near Threatened and Least Concern. A species can also be considered Data Deficient 'when there is inadequate information to make a direct or indirect assessment of its risk of extinction' (IUCN, 2012). During the second stage of the review, a workshop was held in April 2015 by the Tenrec Section of the IUCN Species Survival Commission (SSC) Afrotheria Specialist Group, associated with the 12th African Small Mammals Symposium in Mantasoa, Madagascar, to review the data collected and the draft assessments. At that time, we also developed conservation priorities based on identified threats (as per the Open Standards for the Practice of Conservation; Conservation Measures Partnership, 2013). During the third stage, we conducted a literature review on broader conservation issues in Madagascar, to refine and finalize the priorities.

There is ongoing discussion about tenrec systematics (e.g. Poux et al., 2008; Asher \& Helgen, 2010; Everson et al., 2016). To ensure we consider the latest recognized taxonomies, here we treat the three species of otter-shrew on mainland Africa (once considered tenrecs) as a separate family, the Potamogalidae (following Everson et al., 2016). We similarly follow those authors' synonymization of the genus Limnogale with Microgale (see also Asher \& Helgen, 2010) and placement of the large-bodied shrew tenrecs Microgale dobsoni and Microgale talazaci in the genus Nesogale.

\section{Extinction risk}

Of the 31 species assessed, $24(77.4 \%)$ were categorized as Least Concern, one species (3.2\%) as Data Deficient (Oryzorictes tetradactylus), four species (12.9\%) as Vulnerable (Microgale dryas, Microgale mergulus, Microgale monticola, Microgale nasoloi) and two (6.5\%) as Endangered (Microgale jenkinsae, Microgale jobihely; Table 1). In this assessment, all species were placed in the same Red List category as in previous assessments in 1996 and 2008 (Hoffmann et al., 2011). The status of some species has remained constant for much longer. For example, the aquatic tenrec M. mergulus was also considered Vulnerable 30 years ago when it was first assessed. This consistency across assessments probably reflects the lack of concrete data on the impact of continued forest loss on population numbers. Grandidier's shrew tenrec M. grandidieri, which had not previously been assessed, was categorized as Least Concern.

Five of the six threatened species were categorized as Vulnerable or Endangered under criterion B, in which status is determined primarily on geographical range and number of locations. The two Endangered species had an extent of occurrence $(\mathrm{EOO})<5,000 \mathrm{~km}^{2}$ and were both known from less than five sites: Jenkins' shrew tenrec M. jenkinsae is known only from Mikea National Park (Goodman \& Soarimalala, 2004; Stephenson et al., 2016c) and there are 
TABLE 1 Malagasy tenrecs categorized as threatened or Data Deficient following the IUCN Red List assessment of 2015-2016. The remaining 24 of the 31 Malagasy species assessed were considered Least Concern. Note that in the IUCN Red List, the aquatic tenrec was assessed as Limnogale mergulus, whereas the IUCN SSC Afrotheria Specialist Group now recognizes this as a synonym of Microgale. For full details on each species, including data sources, see Stephenson et al. (2016a,b,c,d,e,f,g). For species assessed and considered Least Concern, see IUCN Afrotheria Specialist Group (2018).

\begin{tabular}{|c|c|c|c|c|c|}
\hline \multirow[b]{2}{*}{ Species } & \multirow{2}{*}{$\begin{array}{l}\text { Red List status }{ }^{1} \\
\& \text { criteria }\end{array}$} & \multicolumn{4}{|l|}{ Justification for listing } \\
\hline & & $\mathrm{AOO} / \mathrm{EOO}^{2}$ & Locations & Habitat & Offtake ${ }^{3}$ \\
\hline Dryad shrew tenrec Microgale dryas & VU B1ab(iii) & $\begin{array}{l}\text { EOO } 7,911 \mathrm{~km}^{2} \\
\left(<20,000 \mathrm{~km}^{2}\right)\end{array}$ & 9 & Declining & No \\
\hline Jenkins' shrew tenrec Microgale jenkinsae & EN B1ab(iii) & $\begin{array}{l}\text { EOO }<2,000 \mathrm{~km}^{2} \\
\left(<5,000 \mathrm{~km}^{2}\right)\end{array}$ & 1 & Declining & No \\
\hline Northern shrew tenrec Microgale jobihely & EN B1ab(iii) & $\mathrm{EOO}<5,000 \mathrm{~km}^{2}$ & $\begin{array}{l}3 \\
\text { (2 populations) }\end{array}$ & Declining & No \\
\hline Aquatic tenrec Microgale mergulus & VU B2ab(ii, iii) & $\mathrm{AOO}<2,000 \mathrm{~km}^{2}$ & 10 & Declining & Yes \\
\hline Montane shrew tenrec Microgale monticola & VU D2 & $\begin{array}{l}\text { EOO } 3,496 \mathrm{~km}^{2} \\
\left(<5,000 \mathrm{~km}^{2}\right)\end{array}$ & 4 & Declining & No \\
\hline Nasolo's shrew tenrec Microgale nasoloi & VU B1ab(iii) & $\begin{array}{l}\text { EOO } 10,183 \mathrm{~km}^{2} \\
\left(<20,000 \mathrm{~km}^{2}\right)\end{array}$ & 4 & Declining & No \\
\hline Four-toed mole tenrec Oryzorictes tetradactylus & $\mathrm{DD}$ & $\begin{array}{l}\text { Most specimens caught } \\
>100 \text { years ago }\end{array}$ & & Unknown & No \\
\hline
\end{tabular}

${ }^{1}$ VU, Vulnerable; EN, Endangered; DD, Data Deficient.

${ }^{2}$ Data on area of occupancy (AOO) and extent of occurrence (EOO) were derived from Goodman et al. (2013).

${ }^{3}$ Offtake refers to direct capture (intentional or unintentional).

only two widely disjunct populations of the northern shrew tenrec M. jobihely (Soarimalala et al., 2010; Stephenson et al., 2016d). All four Vulnerable species are known from 10 sites or less, of which three had an EOO $<20,000 \mathrm{~km}^{2}$ (and were categorized under criterion $\mathrm{B} 1$ ), and one, the aquatic tenrec M. mergulus, which lives exclusively in riverine habitat, had an estimated area of occupancy (AOO) of $<2,000 \mathrm{~km}^{2}$ and was categorized under criterion $\mathrm{B} 2$. The montane shrew tenrec M. monticola was categorized as Vulnerable under criterion $\mathrm{D}$ (which relates to small and very restricted populations), as it is known from only four sites in an EOO of $<20,000 \mathrm{~km}^{2}$.

A single species, the four-toed mole tenrec Oryzorictes tetradactylus, was considered Data Deficient because there is no recent information on its EOO, population and threats (Stephenson et al., 2016g), which meant we could not assess its status. Like many fossorial and semifossorial species, mole tenrecs are difficult to trap, and the majority of records of this species are from more than a century ago.

Amongst the species categorized as Least Concern, the highland streaked tenrec Hemicentetes nigriceps has a relatively small EOO of $15,232 \mathrm{~km}^{2}$ (Goodman et al., 2013). However, it is assumed that its relatively high local abundance and apparent tolerance of anthropogenic habitats mean that the species does not meet any of the subcriteria for a threatened category (Stephenson et al., 2016h). Most species assessed as Least Concern are probably declining because of continued habitat loss across Madagascar, and their status will need to be monitored.

\section{Habitats}

Subtropical/tropical moist lowland forest and subtropical/ tropical moist montane forest are the habitat types (as defined by IUCN, 2018) with the highest number of tenrec species and whose conservation will ensure the greatest tenrec diversity (Table 2). However, western dry forests are key for some species, especially the threatened Jenkins' shrew tenrec and Nasolo's shrew tenrec (Fig. 1; Goodman \& Soarimalala, 2004; Soarimalala \& Goodman, 2008). Riparian habitats are important for the aquatic tenrec (Plate 1), and the four-toed mole tenrec is known from montane ericoid thicket (categorized by IUCN as high-altitude grass or shrublands). 
TABLE 2 Habitat types important for tenrec species in Madagascar. Habitat categories are derived from the IUCN Red List of Threatened Species (IUCN 2018).

\begin{tabular}{|c|c|c|c|}
\hline \multicolumn{2}{|c|}{ Habitat types (IUCN Classification System) } & \multirow{2}{*}{$\frac{\text { No. of tenrec species }}{6}$} & \multirow{2}{*}{$\begin{array}{l}\text { Threatened or Data Deficient tenrec } \\
\text { species in the habitat } \\
\text { Microgale jenkinsae } \\
\text { Microgale nasoloi }\end{array}$} \\
\hline 1.5 & Subtropical/tropical dry forest & & \\
\hline 1.6 & Subtropical/tropical moist lowland forest & 20 & $\begin{array}{l}\text { Microgale mergulus } \\
\text { Microgale dryas }\end{array}$ \\
\hline 1.9 & Subtropical/tropical moist montane forest & 20 & $\begin{array}{l}\text { Microgale jobihely } \\
\text { Microgale monticola } \\
\text { Oryzorictes tetradactylus }\end{array}$ \\
\hline 3.5 & Subtropical/tropical dry shrubland & 2 & Microgale jenkinsae \\
\hline 3.7 & Subtropical/tropical high altitude shrubland & 1 & Oryzorictes tetradactylus \\
\hline 4.7 & Subtropical/tropical high altitude grassland & 1 & Oryzorictes tetradactylus \\
\hline 5.1 & Permanent rivers, streams, creeks & 1 & Microgale mergulus \\
\hline 5.4 & Bogs, marshes, swamps, fens, peatlands & 1 & \\
\hline
\end{tabular}

Some species, such as the Hova mole tenrec Oryzorictes hova, the tailless tenrec and the lowland streaked tenrec Hemicentetes semispinosus, tolerate human-altered habitats, such as gardens or rice fields, to an unknown extent.

\section{Threats}

The main threats facing tenrecs are habitat loss, fragmentation and degradation ( $77 \%$ of species) and hunting for subsistence or bushmeat trade ( $33 \%$ of species). Incidental capture (bycatch) in fishnets and traps is a threat to the aquatic tenrec. Climate change is considered a long-term threat to most species. Lack of knowledge curtails our ability to assess threats and species status and therefore hinders our ability to identify conservation priorities accurately.

Deforestation rates are estimated to range from 0.93 to $2.33 \%$ per year for the humid forest and from 0.46 to $1.17 \%$ per year for dry forest (Grinand et al., 2013). The main cause of forest loss is traditional slash-and-burn agriculture, as well as commercial logging for timber, mining of precious metals and semi-precious gems (such as sapphires), uncontrolled fires and infrastructure development. Dry deciduous forest is increasingly cleared for cash crops such as peanuts for foreign markets (NR, pers. obs.).

Five of the six threatened tenrec species are dependent on native forest habitats, and the aquatic tenrec inhabits clear, free-flowing streams with stony beds that are threatened by the siltation resulting from forest loss. Although the coverage of Madagascar's protected area network quadrupled since 2003 (Gardner et al., 2018), and all tenrec species occur in at least one protected area (Nicoll \& Ratsifandrihamanana, 2014), deforestation is occurring in many parks and reserves where law enforcement capacity is low (Allnutt et al., 2013; Eklund et al., 2016; Gardner et al., 2018).

Spiny tenrecs of the subfamily Tenrecinae are hunted across most of the island, within and outside protected areas, and the meat is consumed for subsistence or sold in local restaurants and urban markets (Garcia \& Goodman, 2003; Randrianandrianina et al., 2010; Jenkins et al., 2011; Reuter et al., 2016). The tailless tenrec, which is widespread and occurs in many habitats, is the most commonly consumed species. It is legal to hunt tenrecs in Madagascar (e.g. the tailless tenrec is on the game species list in decree 2006-400), even though the government acknowledges that hunting and the bushmeat trade are a significant threat to these mammals (Rabarison et al., 2016). The level of offtake is uncertain but can be significant locally. For example, hunters catch up to 40 tenrecs per hunt (Randrianandrianina et al., 2010) and 1,324-5,824 tenrecs are consumed per year in the city of Antsiranana (Reuter \& Sewall, 2016). Until the impact of hunting on population levels is better understood, all exploited species were categorized as Least Concern.

Climate change is a direct threat to biodiversity and a driver of other threats (Hannah et al., 2008). Madagascar ranks third in the world for extreme climate risk (Verisk Maplecroft, 2012). Climate change is predicted to lead to altered habitats and niche availability and changes in species ranges, as demonstrated in lemurs where the range of $60 \%$ of species is expected to decline in 70 years (Brown \& Yoder, 2015). Tenrec habitat, species distribution and abundance are similarly expected to change, but no projections have been made on the likely extent of the change. Because species restricted to mountains have less scope to disperse, montane forest-dwelling species of shrew tenrecs could be most vulnerable to climate change. 


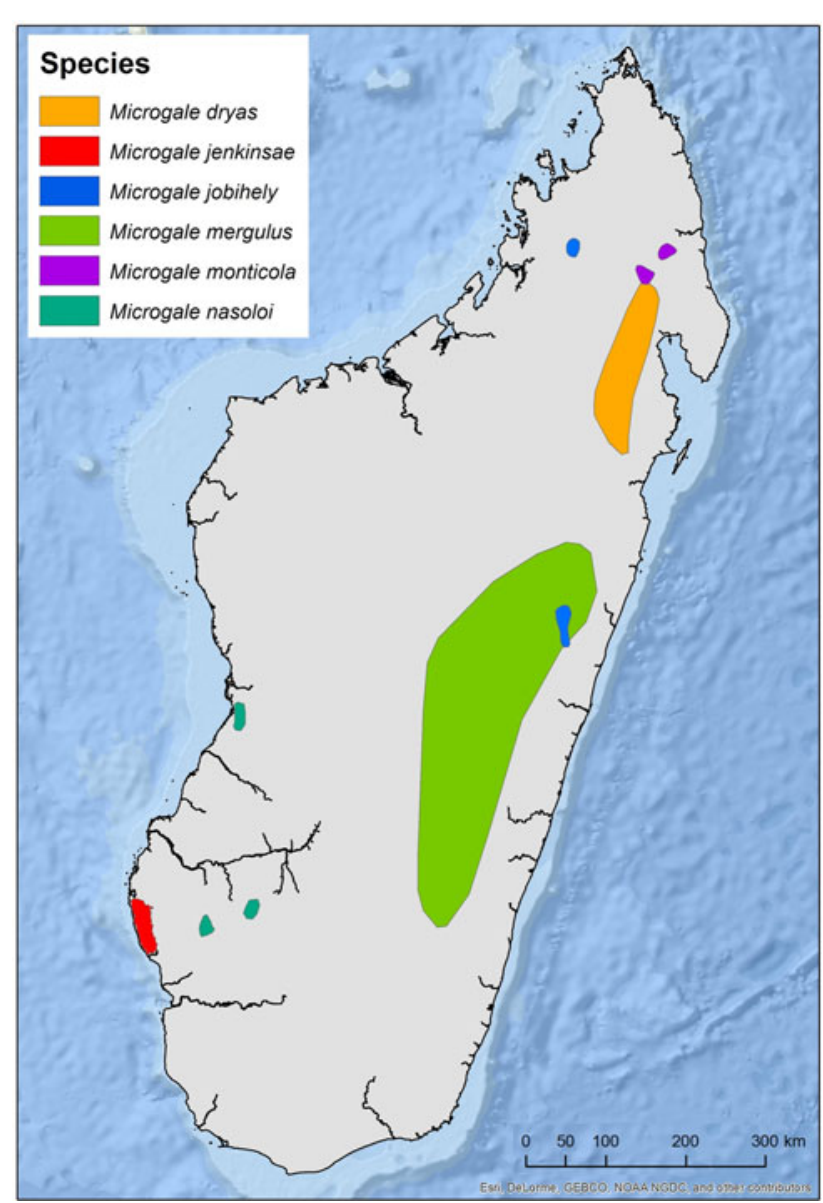

FIG. 1 Distribution map of threatened tenrecs in Madagascar, showing the known key areas for tenrec habitat (map courtesy of Natalia Ocampo; data from IUCN, 2018, based on Goodman et al., 2013).

Madagascar's environment is now more degraded than 25 years ago (Freudenberger, 2010; Goodman et al., in press). Pressures on natural resources are increasing, largely because the human population has risen from 5.1 million in 1960 to 24.9 million in 2016 (World Bank, 2018). The national economy is weak (gross domestic product has halved since 1960) and the World Bank (2016) calculates that $78 \%$ of the population live below the international poverty line (USD 1.90 per person per day), making it one of the 10 poorest countries in the world. Most Malagasy rely on the direct use of natural resources for their livelihoods, which affects many mammals and their habitats.

All threatened tenrec species are known from only a few individuals captured at 10 or fewer locations, making it hard to determine accurately their distribution, abundance, habitat preferences, or population trends. There have been few ecological studies and little information exists on tenrec behaviour. Few Malagasy protected areas have monitoring schemes in place. In addition, tenrec taxonomy is changing regularly as a result of ongoing genetic analyses and

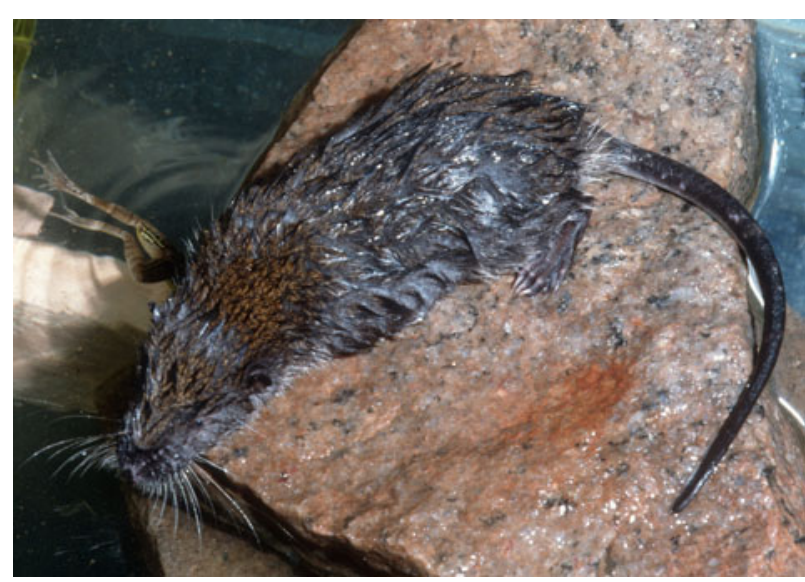

Plate 1 The aquatic tenrec Microgale mergulus is categorized as Vulnerable because of its restricted number of known sites (10) and limited area of occupancy $\left(<2,000 \mathrm{~km}^{2}\right)$. (C) P.J. Stephenson.

morphometric studies of museum specimens. The genus Microgale has been the subject of taxonomic revisions and reorganization (e.g. Stephenson 1995b; Everson et al., 2016), five new species were described in the last 20 years and numerous new species are expected in the next two years (Everson et al., 2018; LEO, unpubl. data). Other key data gaps include the impacts of hunting on spiny tenrecs and the relative dependence of species on intact forest habitats.

\section{Conservation priorities}

Our review suggests conservation efforts for tenrecs need to focus primarily on the seven species identified as threatened or Data Deficient in the IUCN Red List (Table 1). There is a need to improve the management and protection of key habitats and enhance our knowledge base.

\section{Priorities for tenrec habitat conservation}

The main action required to conserve threatened tenrecs is the protection of adequately sized, interconnected blocks of suitable forest habitat, primarily through the creation and effective management of protected areas. Deforestation needs to be halted, particularly within the ranges of threatened tenrecs (Fig. 1). Habitat restoration will be needed in some sites affected by mining or logging. If protection and restoration measures also incorporate riverine forest corridors, enhance connectivity between forest blocks and conserve areas with high levels of altitudinal variation, they will help maximize species' capacity to respond to a changing climate (Hannah et al., 2008). Climate models that overlay the distribution of threatened tenrecs with protected areas and remaining habitat are needed to identify priority areas for protection and restoration efforts in Madagascar. 
The most important habitat types for tenrecs are dry forest, moist lowland forest, moist montane forest and dry shrubland, as well as permanent rivers, streams and creeks (Table 2). The inclusion of a representative sample of these habitats in the protected area network, especially in tenrec range, needs to be verified. There are 15 protected areas currently known to be important for threatened taxa (Table 3) and these sites should be prioritized for conservation action. Government agencies, protected area managers, NGOs, local communities and the private sector will need to work together to improve the integrity and management effectiveness within protected areas. Priorities, as identified by Gardner et al. (2018), include enhancing stakeholder participation, improving law enforcement and reducing the natural resource dependence of local communities through the development of alternative livelihoods.

The livelihood needs of local people need to be addressed if conservation efforts are to succeed (Waeber et al., 2016). Developing alternatives to forest resources such as timber, fuelwood and wild meat would reduce the impact on natural forests. Community forest management schemes, especially those excluding commercial logging (Rasolofoson et al., 2015), and broader forest restoration programmes have demonstrated some promising results in improving resource access and livelihoods in Madagascar (e.g. Mansourian et al., 2016). Rural demand for wild meat can be reduced through price increases driven by law enforcement efforts to reduce supply (see Golden et al., 2014). The protection efforts to reduce supply should be complemented with efforts to reduce demand, for example by increasing the supply of meat from domesticated animals, such as poultry (Apaza et al., 2002; Golden et al., 2014), as long as this supply is environmentally sustainable.

Multi-taxonomic approaches to prioritization can enhance biodiversity conservation (Kremen et al., 2008). Given tenrec habitats are also home to higher profile species such as lemurs, for which more concerted conservation efforts are being made (Reuter \& Venart, 2014; Schwitzer et al., 2014), it would be prudent to integrate tenrecs into conservation projects targeting other threatened species by, for example, promoting protection of areas critical for threatened tenrecs and including tenrecs in education and awareness campaigns. Five of the 15 protected areas conserving threatened tenrecs are also priorities for lemur conservation (Schwitzer et al., 2014): Anjanaharibe-Sud Special Reserve, Ankeniheny-Zahamena Corridor, Makira Natural Reserve, Marojejy National Park and Ranomafana National Park. The national and international NGOs and research institutes that work in and around these five protected areas (including Association Mitsinjo, Centre ValBio, Conservation International, Duke Lemur Center, Lemur Conservation Foundation, The Aspinall Foundation, the Wildlife Conservation Society and WWF), as well as those operating in other sites, should ensure tenrec diversity is considered in their monitoring and conservation programmes (see Table 3).

Efforts to conserve and sustainably manage forests important for tenrecs and other species need to increase their investments in capacity building (Waeber et al., 2016). Priorities should include supporting local communities engaged in resource management and staff from agencies managing protected areas, such as Madagascar National Parks and the Direction de Système des Aires Protégées in the Ministry of Environment, Ecology, Seas and Forests. Approaches also need to be diversified. For example, local village governance bodies, such as dina, which oversee the application of traditional community regulations, could be supported in improving the internal control of habitat exploitation and hunting, in some instances by reinforcing local taboos on tenrecs.

In protected areas harbouring threatened tenrecs (Table 3), the monitoring of key species population trends needs to be integrated into site management. This will require training and capacity building and the development of standardized monitoring protocols adapted to local needs and habitats, using modern techniques such as camera trapping and specialized techniques for fossorial, arboreal and aquatic species that are difficult to trap. Most of the tools and skills are already present in-country, but need to be scaled up. To improve adaptive management, additional monitoring is required to track changes in forest cover, fragmentation and intactness (using data from satellite-based remote sensing and aerial surveys). In parallel, threats and illegal activities need to be tracked, for example with the Spatial Monitoring and Reporting Tool (SMART, 2018), which has been adopted nationally but is not yet used in all protected areas. Madagascar National Parks, the national agency responsible for managing c. $50 \%$ of the island's protected areas, already uses the Management Effectiveness Tracking Tool (WWF, 2007). This tool applies a score card approach to measure a range of variables important for effective management, from legal status and planning to budgets and equipment. It could be introduced to new sites, together with a peer-review process to enhance consistency in application.

\section{Priorities for advancing knowledge on tenrecs}

To improve the data available for IUCN Red List assessments and conservation planning, knowledge gaps in tenrec biology, ecology, taxonomy and distribution need to be filled. All research programmes should incorporate opportunities for building capacity among Malagasy students, scientists and academic institutions to ensure the sustainability of research and monitoring work. Small mammal ecology and conservation should also be integrated into the curricula of national universities. Citizen science 
TABLE 3 Key protected areas for the conservation of threatened tenrecs in Madagascar, with local names given in parentheses. Determining the status of tenrecs and other species in these reserves, and establishing systems to monitor them, is an urgent priority.

\begin{tabular}{|c|c|c|c|c|}
\hline Protected Area $^{1}$ & $\begin{array}{l}\text { Threatened } \\
\text { tenrecs present }\end{array}$ & $\begin{array}{l}\text { Priority } \\
\text { lemur } \\
\text { site }^{2}\end{array}$ & $\begin{array}{l}\text { Critically Endangered } \\
\text { lemurs present }{ }^{3}\end{array}$ & $\begin{array}{l}\text { Examples of NGOs and } \\
\text { associations active in and } \\
\text { around the protected area }\end{array}$ \\
\hline $\begin{array}{l}\text { Ambatovaky Special Reserve } \\
\text { (Réserve Spéciale d'Ambatovaky) }\end{array}$ & Microgale dryas & & & Madagascar National Parks \\
\hline $\begin{array}{l}\text { Ambositra-Vondrozo Forest Corridor } \\
\text { (Paysage Harmonieux Protégé du } \\
\text { Corridor Forestier Ambositra-Vondrozo) }\end{array}$ & Microgale mergulus & & & Conservation International \\
\hline $\begin{array}{l}\text { Alandraza-Analavelo sacred forest } \\
\text { (Monument Naturel de la Forêt Sacrée } \\
\text { Alandraza Analavelo) }\end{array}$ & Microgale nasoloi & & & Missouri Botanical Garden \\
\hline $\begin{array}{l}\text { Andringitra National Park } \\
\text { (Parc National d'Andringitra) }\end{array}$ & Microgale mergulus & & & Madagascar National Parks \\
\hline $\begin{array}{l}\text { Anjanaharibe-Sud Special Reserve } \\
\text { (Réserve Spéciale d'Anjanaharibe-Sud) }\end{array}$ & $\begin{array}{l}\text { Microgale dryas, } \\
\text { Microgale } \\
\text { monticola }\end{array}$ & Yes & $\begin{array}{l}\text { Propithecus candidus, } \\
\text { Indri indri }\end{array}$ & $\begin{array}{l}\text { Duke Lemur Center, Lemur } \\
\text { Conservation Foundation, } \\
\text { Madagascar National Parks }\end{array}$ \\
\hline $\begin{array}{l}\text { Ankeniheny-Zahamena Corridor } \\
\text { (Réserve de Ressources Naturelles du } \\
\text { Corridor Ankeniheny-Zahamena) } \\
\text { AZE tenrec site }\end{array}$ & $\begin{array}{l}\text { Microgale dryas, } \\
\text { Microgale jobihely }\end{array}$ & Yes & $\begin{array}{l}\text { Prolemur simus, Varecia } \\
\text { variegata, Indri indri, } \\
\text { Propithecus diadema }\end{array}$ & $\begin{array}{l}\text { Conservation International, } \\
\text { Association Mitsinjo, } \\
\text { The Aspinall Foundation }\end{array}$ \\
\hline $\begin{array}{l}\text { Bemanevika Landscape } \\
\text { (Paysage Harmonieux Protégé de } \\
\text { Bemanevika) AZE tenrec site }\end{array}$ & Microgale jobihely & & & $\begin{array}{l}\text { Durrell Wildlife } \\
\text { Conservation Trust, } \\
\text { Madagascar National Parks, } \\
\text { The Peregrine Fund, WWF }\end{array}$ \\
\hline $\begin{array}{l}\text { Makira Natural Reserve } \\
\text { (Parc Naturel Makira) }\end{array}$ & $\begin{array}{l}\text { Microgale dryas, } \\
\text { Microgale } \\
\text { monticola }\end{array}$ & Yes & $\begin{array}{l}\text { Propithecus candidus, } \\
\text { Varecia variegata, } \\
\text { Varecia rubra, Indri } \\
\text { indri }\end{array}$ & WCS \\
\hline $\begin{array}{l}\text { Menabe Antimena } \\
\text { (Paysage Harmonieux Protégé de } \\
\text { Menabe Antimena) }\end{array}$ & Microgale nasoloi & & & $\begin{array}{l}\text { Association Fanamby, } \\
\text { Durrell Wildlife } \\
\text { Conservation Trust, WWF }\end{array}$ \\
\hline $\begin{array}{l}\text { Marotandrano Special Reserve } \\
\text { (Réserve Spéciale de Marotandrano) }\end{array}$ & Microgale dryas & & & Madagascar National Parks \\
\hline $\begin{array}{l}\text { Marojejy National Park (Parc National } \\
\text { Marojejy) }\end{array}$ & $\begin{array}{l}\text { Microgale } \\
\text { monticola }\end{array}$ & Yes & $\begin{array}{l}\text { Propithecus candidus, } \\
\text { Indri indri }\end{array}$ & $\begin{array}{l}\text { Duke Lemur Center, Lemur } \\
\text { Conservation Foundation, } \\
\text { Madagascar National Parks }\end{array}$ \\
\hline $\begin{array}{l}\text { Mikea National Park } \\
\text { (Parc National Mikea) } \\
\text { AZE tenrec site }\end{array}$ & $\begin{array}{l}\text { Microgale } \\
\text { jenkinsae }\end{array}$ & & & Madagascar National Parks \\
\hline $\begin{array}{l}\text { Nosy Volo Landscape } \\
\text { (Paysage Harmonieux Protégé de la } \\
\text { Rivière Nosivolo) }\end{array}$ & $\begin{array}{l}\text { Microgale mergulus } \\
\text { (B. Ramahefasoa, } \\
\text { pers. comm.) }\end{array}$ & & & \\
\hline $\begin{array}{l}\text { Ranomafana National Park } \\
\text { (Parc National Ranomafana) }\end{array}$ & Microgale mergulus & Yes & $\begin{array}{l}\text { Prolemur simus, } \\
\text { Cheirogaleus sibree, } \\
\text { Varecia variegata, } \\
\text { Hapalemur aureus }\end{array}$ & $\begin{array}{l}\text { Centre International de } \\
\text { Formation pour la } \\
\text { Valorisation de la } \\
\text { Biodiversité } \\
\text { (Centre ValBio), } \\
\text { Madagascar National Parks }\end{array}$ \\
\hline $\begin{array}{l}\text { Zombitse-Vohibasia National Park } \\
\text { (Parc National Zombitse-Vohibasia) }\end{array}$ & Microgale nasoloi & & & Madagascar National Parks \\
\hline
\end{tabular}

${ }^{1}$ Alliance for Zero Extinction (AZE) sites contain $95 \%$ or more of the remaining population of one or more tenrec species listed as Endangered or Critically Endangered (sensu Ricketts et al., 2005).

${ }^{2}$ Priority lemur site details from Schwitzer et al. (2013, 2014).

${ }^{3}$ Lemur species are listed only for priority lemur sites. 
research projects conducted in collaboration with local people could help access traditional knowledge and improve our understanding of tenrec distribution, habitats and threats (especially for larger species).

Priority areas for research include investigating: (1) The ecology, distribution and abundance of the four-toed mole tenrec, using appropriate pitfall trapping techniques to survey areas close to its known range (e.g. in and around Andringitra National Park). (2) The distribution of the aquatic tenrec, using live trapping or camera trapping and/or scat surveys. Success would be enhanced by engaging the help of protected area managers and fishing communities. (3) The range of the highland streaked tenrec, to verify whether it is threatened under B criteria. (4) The extent to which tenrec species diversity and abundance are affected by forest structure, habitat degradation, fishing bycatch, hunting and climate change. (5) Methods and protocols required for monitoring tenrecs, including the compilation of suitable guidelines and tools (e.g. identification guides, manuals describing trapping methods, collecting DNA samples, etc.). (6) Habitat cover trends and land use changes, using opensource satellite-based remote sensing data.

The study of Tenrecidae systematics, including taxonomy, needs to be continued to identify cryptic species and clarify species limits and diversity. Two newly delineated but unnamed species of Oryzorictes need to be described, which will involve confirming the identities of several holotypes (Everson et al., 2018). The likely presence of a cryptic species in the genus Geogale also requires investigation (Poux et al., 2008; Everson et al., 2016).

Research data need to be made available to decision makers in governmental and non-governmental agencies to inform and influence policy, especially relating to protected area management and the control of hunting and mining. The presence of long-term research teams in protected areas may also help deter illegal hunting and logging (Schwitzer et al., 2014).

\section{Conclusions}

Small mammals are often given less scientific and conservation attention than larger species even though they are just as threatened (Entwistle \& Stephenson, 2000; Stephenson, 2017). In Madagascar, native small mammals are notably diverse and entirely endemic to this island, so it is vital to address the threats facing this neglected group. The largest threat facing tenrecs, habitat loss, reflects a global trend for small mammals whose conservation status is mostly determined by range size and number of locations (Schipper et al., 2008; Kennerley et al., 2018). The only previous assessment of tenrec conservation needs (Nicoll \& Rathbun, 1990) highlighted many of the same priorities presented here around habitat conservation and improving our knowledge of species distribution and status. Although our knowledge of tenrecs has advanced considerably since 1990, no conservation projects have targeted the Tenrecidae explicitly. Therefore, in the next 10 years, there needs to be a strategic effort to integrate the forest habitats of key threatened endemic species such as tenrecs into broader conservation and sustainable development programmes, and to increase the scientific study and monitoring of tenrecs and other mammals. The conservation priorities we have identified need to be translated into fundable projects, following consultative planning processes (e.g. Conservation Measures Partnership, 2013) that involve key stakeholders, such as government agencies, civil society bodies, local communities, business and industry, and donors. The existence of numerous conservation projects across Madagascar, and the continued interest of international donors and NGOs, suggests that implementing tenrec projects will be economically and practically feasible, especially if linked to higher profile taxa. Ultimately, however, only a more concerted effort by the government of Madagascar and its civil society partners and donors to conserve and sustainably manage the country's remaining forests will ensure the continued survival of endemic tenrec species.

Acknowledgements We thank Natalia Ocampo (ETH Zürich) for compiling Fig. 1.

Author contributions IUCN Red List assessments in 2015-2016: PJS, VS and SMG; data contribution: MEN, VA, KME, MH, PDJ, LEO, MR, FR, DR, VR and NR; review of assessments: AT; first draft: PJS, with subsequent input from all co-authors. PJS, VS, SMG, MEN, KME, MH, PDJ, LEO, MR and AT are current members of the IUCN SSC Afrotheria Specialist Group.

\section{Conflicts of interest None.}

Ethical standards This review complies with the journal's Code of Conduct for authors contributing articles.

\section{References}

Allnutt, T.F., Asner, G.P., Golden, C.D. \& Powell, G.V. (2013) Mapping recent deforestation and forest disturbance in northeastern Madagascar. Tropical Conservation Science, 6, 1-15.

Apaza, L., Wilkie, D., Byron, E., Huanca, T., Leonard, W., Perez, E. et al. (2002) Meat prices influence the consumption of wildlife by the Tsimane Amerindians of Bolivia. Oryx, 36, 382-388.

Asher, R.J. \& Helgen, K.M. (2010) Nomenclature and placental mammal phylogeny. BMC Evolutionary Biology, 10, 102.

Brooks, T.M., Butchart, S.H., Cox, N.A., Heath, M., Hilton-Taylor, C., Hoffmann, M. et al. (2015) Harnessing biodiversity and conservation knowledge products to track the Aichi targets and sustainable development goals. Biodiversity, 16, 157-174. Brown, J.L. \& Yoder, A.D. (2015) Shifting ranges and conservation challenges for lemurs in the face of climate change. Ecology and Evolution, 5, 1131-1142.

Conservation Measures Partnership (CMP) (2013) Open Standards for the Practice of Conservation, Version 3. Conservation Measures Partnership, Bethesda, USA. 
EisenberG, J.F. \& Gould, E. (1970) The tenrecs: a study in mammalian behavior and evolution. Smithsonian Contributions to Zoology, 27, 1-137.

Eklund, J., Blanchet, F.G., Nyman, J., Rocha, R., Virtanen, T. \& CABEZA, M. (2016) Contrasting spatial and temporal trends of protected area effectiveness in mitigating deforestation in Madagascar. Biological Conservation, 203, 290-297.

Entwistle, A.C. \& Stephenson, P.J. (2000) Small mammals and the conservation agenda. In Priorities for the Conservation of Mammalian Biodiversity: Has the Panda had its Day? (eds. A.C. Entwistle \& N. Dunstone), pp. 119-139. Cambridge University Press, Cambridge, UK.

Everson, K.M., Soarimalala, V., Goodman, S.M. \& Olson, L.E. (2016) Multiple loci and complete taxonomic sampling resolve the phylogeny and biogeographic history of tenrecs (Mammalia: Tenrecidae) and reveal higher speciation rates in Madagascar's humid forests. Systematic Biology, 65, 890-909.

Everson, K.M., Hildebrandt, K.B.P., Goodman, S.M. \& Olson, L.E (2018) Caught in the act: incipient speciation across a latitudinal gradient in a semifossorial mammal from Madagascar, the mole tenrec Oryzorictes hova (Tenrecidae). Molecular Phylogenetics and Evolution, 126, 74-84.

Freudenberger, K. (2010) Paradise Lost? Lessons From 25 Years of USAID Environment Programs in Madagascar. International Resources Group, Washington, DC, USA.

Garcia, G. \& Goodman, S.M. (2003) Hunting of protected animals in the Parc National d'Ankarafantsika, north-western Madagascar. Oryx, 37, 115-118.

Gardner, C.J., Nicoll, M.E., Birkinshaw, C., Harris, A., Lewis, R. E., Rakotomalala, D. \& Ratsifandrihamanana, A.N. (2018) The rapid expansion of Madagascar's protected area system. Biological Conservation, 220, 29-36.

Golden, C.D., Bonds, M.H., Brashares, J.S., Rasolofoniaina, B.J.R. \& KREMEN, C. (2014) Economic valuation of subsistence harvest of wildlife in Madagascar. Conservation Biology, 28, 234-243.

Goodman, S.M. \& Soarimalala, V. (2004) A new species of Microgale (Lipotyphla: Tenrecidae: Oryzorictinae) from the Forêt des Mikea of southwestern Madagascar. Proceedings of the Biological Society of Washington, 117, 251-265.

Goodman, S.M., Raherilalao, M.J. \& Wohlhauser, S. (eds.) (in press) Les Aires Protégées Terrestres de Madagascar: Leur Histoire, Description et Biote/The Terrestrial Protected Areas of Madagascar: Their History, Description and Biota. Association Vahatra, Antananarivo, Madagascar.

Goodman, S.M., Soarimalala, V., Raheriarisena, M. \& Rakotondravony, D. (2013) Small mammals or tenrecs (Tenrecidae) and rodents (Nesomyidae). In Atlas D'une Sélection de Vertebrés Terrestres de Madagascar/Atlas of Selected Land Vertebrates of Madagascar (eds. S.M. Goodman \& M.J. Raherilalao), pp. 211-269. Association Vahatra, Antananarivo, Madagascar.

Grinand, C., Rakotomalala, F., Gond, V., Vaudry, R., Bernoux, M. \& Vieilledent, G. (2013) Estimating deforestation in tropical humid and dry forests in Madagascar from 2000 to 2010 using multi-date Landsat satellite images and the random forests classifier. Remote Sensing of Environment, 139, 68-80.

Hannah, L., Dave, R., Lowry, II, P.P., Andelman, S., Andrianarisata, M., Andriamaro, L. et al. (2008) Climate change adaptation for conservation in Madagascar. Biology Letters, 4, 590-594.

Harper, G. J., Steininger, M.K., Tucker, C.J., Juhn, D. \&. Haw kins, F. (2007) Fifty years of deforestation and forest fragmentation in Madagascar. Environmental Conservation, 34, 325-333.

Hoffmann, M., Belant, J.L., Chanson, J., Cox, N.A., Lamoreux, J., Rodrigues, A.S.L. et al. (2011) The changing fates of the world's mammals. Philosophical Transactions of the Royal Society B, 366, 2598-2610.

IUCN (2012) IUCN Red List Categories and Criteria: Version 3.1. 2nd edition. IUCN, Gland, Switzerland and Cambridge, UK.

IUCN (2018) The IUCN Red List of Threatened Species. Version 2018-2. Http://www.iucnredlist.org [accessed 19 November 2018].

IUCN Afrotheria Specialist Group (2018). Afrotherian systematics. Http://afrotheria.net/systematics.php [accessed 19 November 2018].

Jenkins, R.K.B., Keane, A., Rakotoarivelo, A.R., Rakotomboavonjy, V., Randrianandrianina, F.H., Razafimanahaka, H.J. et al. (2011) Analysis of patterns of bushmeat consumption reveals extensive exploitation of protected species in eastern Madagascar. PLOS ONE, 6, e2757o.

Kennerley, R.J., Lacher, Jr, T.E., Mason, V., McCay, S., Roach, N., Stephenson, P.J. et al. (2018) Conservation priorities and actions for the orders Cingulata, Pilosa, Afrosoricida, Macroscelidea, Eulipotyphla, Dermoptera and Scandentia. In Handbook of the Mammals of the World - Volume 8. Insectivores, Sloths and Colugos (eds D.E. Wilson \& R.A. Mittermeier), pp. 15-27. Lynx Edicions, Barcelona, Spain.

Kremen, C., Cameron, A., Moilanen, A., Phillips, S.J., Thomas, C.D., Beentje, H. et al. (2008) Aligning conservation priorities across taxa in Madagascar with high-resolution planning tools. Science, 320, 222-226.

Mansourian, S., Razafimahatratra, A., Ranjatson, P. \& Rambeloarisao, G. (2016) Novel governance for forest landscape restoration in Fandriana Marolambo, Madagascar. World Development Perspectives, 3, 28-31.

Nicoll, M. E. \& Rathbun, G.B. (1990) African Insectivora and Elephant-Shrews: an Action Plan for their Conservation. IUCN SSC Insectivore, Tree-Shrew and Elephant-Shrew Specialist Group. IUCN, Gland, Switzerland.

Nicoll, M. \& Ratsifandrihamanana, N. (2014) The growth of Madagascar's protected areas system and its implications for tenrecs (Afrosoricida, Tenrecidae). Afrotherian Conservation, 10, 4-8.

Olson, L.E. \& Goodman, S.M. (2003) Phylogeny and biogeography of tenrecs. In The Natural History of Madagascar (eds S.M. Goodman \& J.P. Benstead ), pp. 1235-1242. University of Chicago Press, Chicago, USA, and London, UK.

Olson, L.E., Rakotomalala, Z., Hildebrandt, K.B.P., Lanier, H.C., Raxworthy, C.J. \& Goodman, S.M. (2009) Phylogeography of Microgale brevicaudata (Tenrecidae) and description of a new species from western Madagascar. Journal of Mammalogy, 90, 1095-1110.

Poux, C., Madsen, O., Glos, J., De Jong, W.W. \& Vences, M. (2008) Molecular phylogeny and divergence times of Malagasy tenrecs: influence of data partitioning and taxon sampling on dating analyses. BMC Evolutionary Biology, 8, 102.

Rabarison, H., Randriamahaleo, S.I., Andriambelo, F.M. \& Randrianasolo, H.L. (2016) National Biodiversity Strategy and Action Plan (2015-2025). Ministère de l'Environnement, de L'Ecologie, de la Mer et des Forêts, Antananarivo, Madagasacar.

Randrianandrianina, F.H., Racey, P.A. \& Jenkins, R.K.B. (2010) Hunting and consumption of mammals and birds by people in urban areas of western Madagascar. Oryx, 44, 411-415.

Rasolofoson, R.A., Ferraro, P.J., Jenkins, C.N. \& Jones, J.P. (2015) Effectiveness of community forest management at reducing deforestation in Madagascar. Biological Conservation, $184,271-277$.

Reuter, K.E. \& Sewall, B.J. (2016) Taboos and sustainability of tenrec hunting in Madagascar. Afrotherian Conservation, 12, 11-15.

Reuter, K. \& Venart, L. (2014) Announcing the lemur conservation network: working together to save lemurs from extinction. Primate Conservation, 28, 37-38. 
Reuter, K.E., Randell, H., Wills, A.R., Janvier, T.E., Belalahy, T.R. \& SEWALL., B.J. (2016) Capture, movement, trade, and consumption of mammals in Madagascar. PLOS ONE, 11, e0150305.

Ricketts, T.H., Dinerstein, E., Boucher, T., Brooks, T.M., Butchart, S.H.M., Hoffmann, M. et al. (2005) Pinpointing and preventing imminent species extinctions. Proceedings of the National Academy of Sciences of the United States of America, $51,18497-18501$.

Schipper, J., Chanson, J.S., Chiozza, F., Cox, N.A., Hoffmann, M., Katariya, V. et al. (2008) The status of the world's land and marine mammals: diversity, threat, and knowledge. Science, 322, 225-230.

Schwitzer, C., Mittermeier, R.A., Davies, N., Johnson, S., Ratsimbazafy, J., Razafindramanana, J. et al. (2013) Lemurs of Madagascar: A Strategy for their Conservation 2013-2016. IUCN SSC Primate Specialist Group, Bristol, UK.

Schwitzer, C., Mittermeier, R. A., Johnson, S. E., Donati, G., Irwin, M., PEAcock, H. et al. (2014) Averting lemur extinctions amid Madagascar's political crisis. Science, 343, 842-843.

Soarimalala, V. \& Goodman, S.M. (2008) New distributional records of the recently described and endangered shrew tenrec Microgale nasoloi (Tenrecidae: Afrosoricida) from central western Madagascar. Mammalian Biology, 73, 468-471.

Soarimalala, V., Raheriarisena, M. \& Goodman, S.M. (2010) New distributional records from central-eastern Madagascar and patterns of morphological variation in the Endangered shrew tenrec Microgale jobihely (Afrosoricida: Tenrecidae). Mammalia, 74, 187-198.

SMaRt (Spatial Monitoring and Reporting Tool) (2018) Http://smartconservationsoftware.org [accessed 19 November 2018].

Stephenson, P.J. (1993a) The small mammal fauna of Réserve Spéciale d'Analamazaotra, Madagascar: the effects of human disturbance on endemic species diversity. Biodiversity and Conservation, 2, 603-615.

STEPHENSON, P.J. (1993b) The impacts of tourism on nature reserves in Madagascar: Périnet, a case study. Environmental Conservation, 20, 262-265.

Stephenson, P.J. (1994) Deforestation threatens the Tenrecidae of Madagascar. Species, 23, 66-67.

Stephenson, P.J. (1995a) Small mammal microhabitat use in lowland rain forest of north-east Madagascar. Acta Theriologica, 40, 425-438.

Stephenson, P.J. (1995b) Taxonomy of shrew-tenrecs (Microgale spp.) from eastern and central Madagascar. Journal of Zoology, 235, 339-350.

Stephenson, P.J. (2017) Small mammal monitoring: why we know so little about the Afrotheria. Afrotherian Conservation, 13, 34-42.

Stephenson, P.J. \& Racey, P.A. (1995) Resting metabolic rate and reproduction in the Insectivora. Comparative Biochemistry and Physiology, 112A, 215-223.

Stephenson, P.J., Randriamahazo, H., Rakotoarison, N. \& RACEY, P.A. (1994) Conservation of mammalian species diversity in
Ambohitantely Special Reserve, Madagascar. Biological

Conservation, 69, 213-218.

Stephenson, P.J., Soarimalala, V. \& Goodman, S.M. (2016a) Limnogale mergulus. In The IUCN Red List of Threatened Species 2016. Http://dx.doi.org/10.2305/IUCN.UK.2016-1.RLTS.

T11979A9718969o.en [accessed 22 January 2018].

Stephenson, P.J., Soarimalala, V. \& Goodman, S.M. (2016b) Microgale dryas. In The IUCN Red List of Threatened Species 2016. Http://dx.doi.org/10.2305/IUCN.UK.2016-1.RLTS.T13356A97191108. en [accessed 22 January 2018].

Stephenson, P.J., Soarimalala, V. \& Goodman, S.M. (2016c) Microgale jenkinsae. In The IUCN Red List of Threatened Species 2016. Http://dx.doi.org/10.2305/IUCN.UK.2016-1.RLTS.

T62015A97192062.en [accessed 22 January 2018].

Stephenson, P.J., Soarimalala, V. \& Goodman, S.M. (2016d) Microgale jobihely. In The IUCN Red List of Threatened Species 2016. Http://dx.doi.org/10.2305/IUCN.UK.2016-1.RLTS.

T136628A21282528.en [accessed 22 January 2018].

Stephenson, P.J., Soarimalala, V. \& Goodman, S.M. (2016e) Microgale monticola. In The IUCN Red List of Threatened Species 2016. Http://dx.doi.org/10.2305/IUCN.UK.2016-1.RLTS.

T29462A97200712.en [accessed 22 January 2018].

Stephenson, P.J., Soarimalala, V. \& Goodman, S.M. (2016f) Microgale nasoloi. In The IUCN Red List of Threatened Species 2016. Http://dx.doi.org/10.2305/IUCN.UK.2016-1.RLTS.

T62017A97200965.en [accessed 22 January 2018].

Stephenson, P.J., Soarimalala, V. \& Goodman, S.M. (2016g) Oryzorictes tetradactylus. In The IUCN Red List of Threatened Species 2016. Http://dx.doi.org/10.2305/IUCN.UK.2016-1.RLTS. T40591A97203290.en [accessed 22 January 2018].

Stephenson, P.J., Soarimalala, V. \& Goodman, S.M. (2016h) Hemicentetes nigriceps. In The IUCN Red List of Threatened Species 2016. Http://dx.doi.org/10.2305/IUCN.UK.2016-1.RLTS.

T62011A97189172.en [accessed 22 January 2018].

Verisk Maplecroft (2012) Climate Change Vulnerability Index. Https:// maplecroft.com/about/news/ccvi.html [accessed 19 November 2018].

Waeber, P.O., Wilmé, L., Mercier, J.R., Camara, C.C. \& Lowry, II, P.P. (2016) How effective have thirty years of internationally driven conservation and development efforts been in Madagascar? PLOS ONE, 11, eo161115.

World B ANK (2016) Poverty and Shared Prosperity 2016: Taking on Inequality. World Bank, Washington, DC, USA. Https://doi.org/10.1596/978-1-4648-0958-3 [accessed 19 November 2018].

World Bank (2018) Madagascar Data. World Bank, Washington, DC, USA. Https://data.worldbank.org/country/madagascar [accessed 19 November 2018].

WWF (2007) Management Effectiveness Tracking Tool: Reporting Progress at Protected Area Sites. 2nd edition. WWF International, Gland, Switzerland. 